\title{
Directive Speech Acts in Aisha Saeed's Novel Amal Unbound
}

\author{
Amarylis Duta Pertiwi ${ }^{*}$, Mytha Candria $^{2}$, and Dwi Wulandari ${ }^{3}$ \\ ${ }^{1}$ English Department, Faculty of Humanities, Diponegoro University, Indonesia \\ ${ }^{2}$ English Department, Faculty of Humanities, Diponegoro University, Indonesia \\ ${ }^{3}$ English Department, Faculty of Humanities, Diponegoro University, Indonesia
}

\begin{abstract}
Communication within society comprises diverse linguistic choices influenced by social interaction. This study discusses how structures of utterances and types of directive illocutionary acts pertain to the characters' qualities and non-linguistic factors in Amal Unbound (2018) by Aisha Saeed. This analysis aims to find out the connection between utterances the characters' qualities such as age, occupation, education, relationship, social status, and non-linguistic factor like the topic or purpose. The underlying theory used in this study is Bach and Harnish's directive speech act categorization. This study was conducted using qualitative method since it involves discussion on linguistic data (words, phrases, sentences, and utterances). The result of the analysis shows that the utterances of the novel's characters are affected by the quality they possess and surrounding non-linguistic factors. In conclusion, understanding illocutionary acts open our eyes of the significance of appropriate uses of language in social practice.
\end{abstract}

\section{Introduction}

The covid-19 pandemic has changed all the way human do their activity. Communication is no exception. Nowadays, we communicate through online platforms instead of talking face-to-face. During this time, a phenomenon of the directive has proliferated to tackle the pandemic. Directive means that one wants the other to do something. As we notice, there are many warnings, reminders, messages, etc., that we can easily find in social media, online platforms, or along the road like 'stay at home' or 'use your mask'. This language usage should be placed properly according to the goals, situation, participants (the reader), and so on. However, people probably do not care to read this warning, reminder, or message. First, people are interested in fun social media content, and their fingers keep scrolling down. Second, when this directive is found along the road, they are just busy driving. That is why analyzing directives in literature is much more interesting. Therefore, we can understand directives deeply, from the forms, functions, and qualifications to create directives.

Communication is one of the most fundamental aspects of our everyday life. People intuitively express their thought to others as human beings nature. Such thought can be

* Corresponding author: vincentia.alicia00@gmail.com 
delivered in writing, speech, sign language, and perhaps in other forms. Through communication, people in society do not produce grammatical and logical output only but also cover a number of activities simultaneously, such as sharing information, asking for help, promising, and so on. Therefore, the communicative activity becomes the foundation to build a relationship between the participants and activities. Although we cannot have a direct conversation during the pandemic, social media has been a bridge between participants to build their relationships.

The concept above is in line with what Austin, as cited in Levinson (1983) [1], proposes that utterance can actively do an action. That leads us to the term of the Speech Act. Mey (2001) [2] describes "speech acts are verbal actions happening in the world" (p. 95). There are three elements of speech acts given by Austin : locutionary act, illocutionary act, and perlocutionary act. locutionary act is the utterance or meaningful linguistic unit. Illocutionary act is doing something by the utterance. The perlocutionary act is the effect of the intended meaning of the utterance. Although there are three elements in speech act, the main focus in speech act analysis is an illocutionary act. Those elements actually cannot be separated ; they are one. Prelocutionary act occurs because there is an illocutionary act, and illocutionary act exist because there is a meaningful linguistic sentence. When we say something, we actually do an action - the production of our thought-verbal utterances-both covers grammatical output and its purpose or intention. Therefore, an action is enacted with the medium of language - three basic aspects that must exist in speech acts speaker, hearer and action [3].

There are distinct elements of illocutionary acts, according to some experts such as Austin (1962), Searle (1979), and Bach and Harnish (1979) [4, 5]. The main concern of this study is directive speech acts. Directive speech acts both exist in Searle (1979) and Bach and Harnish (1979). Searle [4] describes directives as an attempt to get the hearer to do something. Bach and Harnish (1979) [5] account directives as to the intention from the speaker that his attitude will be taken as a reason for the hearer to accomplish it. This paper focuses on directive categorization according to Bach and Harnish. Their six classifications of directives embody Requestives, Requirements, Questions, Prohibitives, Advisories, and Permissions.

Social maintenance is the primary function of communication [6]. In order to achieve great continual communication, we must have ample linguistic ability, such as interpreting what the speaker says, replying to proper answers, and selecting the correct vocabulary. That is why Fairclough (2013) [7] says that a language is a form of social practice. Then, we can assume that linguistic processes are socially constructed. It implies that our linguistic choices are determined by our social interaction. People must be aware of various factors while speaking, like the topics, the purpose, the participants, the content, etc. In short, linguistic and non-linguistic phenomena in social convention have an inseparable connection that is essential for communication.

Because language is socially constructed, language often pertains to power. The directive is likely the most classification linked to power [7, 8]. Power can be depicted into two types: power over material control and metaphysical in nature [9]. In the conversation, there must be the one who has less power, and the other has more power. As a result, the relationship between them is in an unequal position. The directive has a special 'effect' that the hearer agrees to fulfil what the speaker says. Thus, directive tends to have a relationship with the concept of power. The unequal power between participants can lead to different types of utterances that are produced. The production of language is the result of unequal power. Holmes stated that our speech could reveal our identity [10]. For example, a landlord will have the tendency to produce more Requirements or Prohibitives towards the tenants when speaking about rules in the apartment: 'Pay the bill before 25th each month' or 'You must not carry any pet inside the apartment' because the landlord has the control during the situation. 
This phenomenon can be reflected in literary works too. Each character in "Amal Unbound" novel by Aisha Saeed (2018) reflects the various background of power, looking at the setting of the story, which is situated in a countryside area. Consequently, they have different choices and points of view in terms of their linguistic use. Using Bach and Harnish's classification of Directives, we were able to find the connection between utterances, character's qualities, and non-linguistic factors. This can show how the production of language is affected by non-linguistic factors and how the form of the directive is used toward a different level of power.

Amal Unbound is a best-seller novel written by Aisha Saeed. Aisha's work has been acknowledged by international readers. The story narrates a 12-year-old Pakistani girl who suffers from inequality in her life. She has to leave school and help her family to accomplish chores and pay the debt. Amal faces both new things and difficulties when she works as a servant in Khan Estate. In the end, she can free herself and reunite with her family again.

Holmes (2003) [10] says that the directive speech act can get influence by the distance between the speaker and the interlocutors. Generally, a speaker will refer to use Requestive when he is not familiar with his interlocutor, but when they have an intimate relationship, the speaker will have a bigger probability to use Requirement. It also can be expressed in different forms: declarative, interrogative, or imperative. Declarative functions to make a statement, interrogative functions to make a question, and imperative functions to give a command. The form of utterance and types of directive's function are related. When they match, it is said that the directive occurs indirectly. On the contrary, indirectness occurs when the form and the function do not concur. Direct speech indicates that the hearer and the speaker know each other well, and indirect speech indicates that they do not have such a relationship. That idea is proposed by Yule (1996) [11]. However, this paper will not consider the discussion further on direct and indirect speech but will consider different forms of utterance produced by the speaker to include in data and discussion.

As mentioned previously, directives according to Bach and Harnish cover six different classifications:

\section{Requestives}

The speaker wants the hearer to do an action. The hearer is expected to consider at least part of the speaker's intention as the reason to do it. Therefore, the hearer is not forced to do it.

2. Questions

This second type of directive is similar to Requestives. The difference is on 'what is asked'. Requestives ask for an action, while Questions ask for information. The speaker needs the hearer to answer him with information.

3. Requirements

The speaker requires the hearer to fulfil the speaker's desire, and the hearer must do it. The degree of force is stronger than the Requestives. It means that the only option is to do that action. There is an adequate reason why the hearer must do what is said. Indeed, to produce Requirements, the speaker must have authority over the hearer. The authority can be physical, psychological, or institutional.

4. Prohibitives

Prohibitives are actually Requirements that the speaker requires the hearer not to do an action. The speaker who has authority over the hearer does not allow a certain action to occur. The hearer is prohibited from doing this or that.

5. Permissives

If Prohibitives are Requirement, Permissives are the opposite of Prohibitives. The speaker allows the hearer to do a particular action freely. In other words, the hearer feels free to do an action. The action is entitled and attached to the hearer. Similar to Requirement and 
Prohibitive, the speaker needs authority over the hearer to produce this fifth type of directive.

6. Advisories

The speaker does not express his desire to the hearer about performing an action, but he hopes that the hearer will have a belief to do the action instead. What is expected is the conviction of the hearer to do it. Doing the action is a better and good choice because it is probably beneficial for the hearer.

The study of directive speech acts in literary work has been done by many researchers. Mahendra (2018) [12] had carried out a directive analysis entitled "Direct and Indirect Directive Illocutionary Acts in the Movie Penguin of Madagascar", which concluded that the interpretation of the meaning heavily relies on the context during the conversation. The next study was done by Pamungkas et al. (2018) [13] entitled "The Function of Directive Speech Acts in Gamal Komandoko' Indonesian Archipelago Folklore Text”. It revealed that Gamal Komandoko' Folklore Text has many directive functions such as commanding, advising, challenging, requesting, etc. Similarly, Winarti et al. (2015) [14] examined different categories of directive speech act, the context, and the morality issues in Javanese traditional song Tembang Dolanan. Their conclusion shows that Tembang Dolanan was far from politeness, and it consisted of inequality of power. Different from those previous studies, this research focuses on directive categorization, according to Bach and Harnish (1979), to classify types of the directive and find out the relation between the utterance, character's qualities, and other non-linguistic factors deeply.

The research was carried out in qualitative research. The identification and analysis deal with linguistic data of directive categorization. The data were collected through purposive sampling. Utterances are selected if they are classified as directive speech acts, and the utterances must occur in direct conversation with Amal as the main character. The utterances may have imperative, interrogative, or declarative forms. The method of analyzing data is content analysis. The analytic content approach leads to subjective interpretation and depends on the context. It will be used to interpret and decide the types of the directive. Analysis of the data will not discuss further on direct and indirect speech. Directness and Indirectness are used for analysis when talking about the relationship between participants.

\section{Result and Discussion}

Table 1. The total of directives.

\begin{tabular}{|l|c|c|}
\hline \multirow{2}{*}{\multicolumn{1}{|c|}{ Directives }} & \multicolumn{2}{c|}{ Total of number } \\
\cline { 2 - 3 } & Direct & Indirect \\
\hline Requestives & 5 & 24 \\
\hline Questions & 184 & - \\
\hline Requirements & 54 & 18 \\
\hline Prohibitives & 12 & 4 \\
\hline Permissives & - & 5 \\
\hline Advisories & 7 & 18 \\
\hline & 262 & 69 \\
\hline
\end{tabular}

\subsection{Requestives}

Requestives mean that the speaker intently expresses her desire to the hearer and hopes that the hearer agrees to do it. The total of Requestives is twenty seven (27) times.

Datum 1 
Jawad Sahib : "And who said you could walk in here and take my things?"

Amal : "I shouldn't have. And I'm sorry. But these books ... you have so many. There's dust gathering on their spines. I couldn't help it. Forgive me, I've missed reading so much.” (p. 112)

Amal has to work as a servant at Khan Estate to pay her family debt and for her disrespectful attitude toward Jawad Sahib. Jawad forced Amal's father to let her work at the estate. He is an evil person, and everyone in the village is scared of him.

There are many books in the library at Khan Estate, which belongs to Jawad Sahib. Amal knows about the library, and then she sneaks into it and borrows a book because she likes reading books. She has not read books since the last time she quitted attending school. When she has done reading the book, Jawad Sahib knows that somebody sneaks into his library. Amal has just lied to Jawad Sahib about the book. She is actually not dusting the books but trying to return the book.

Amal's utterance "forgive me" is categorized as Requestive. Amal requests Jawad to forgive and release her for going to his library without his permission. It is not Requirement because Amal does not force Jawad to do such action. Here, Jawad can either forgive her or not. Jawad is Amal's master and the library owner; therefore, he is the one having control of the situation. It is impossible for Amal to use Requirement for this condition.

\section{Datum 2}

Jawad Sahib : "My mother loves these. You won't mind if I take this for her, will you ? Of course I'll pay you for it and you can buy more."

Amal

Jawad Sahib

$:$ "It was the last one."

Amal goes to Shaukat's store to buy food. She is excited to go out of the home for a while after Seema; her younger sister helps her to watch their little sisters. Unexpectedly, a car hit Amal while she was heading home. A man named Jawad Sahib from the car approaches and offers her help, but she denies him. Then, the man hands her a handful of money to Amal if she agrees to exchange it with the pomegranate that she has. Amal strongly rejects his offer. She thinks that the man looks at her as a beggar. Quickly Amal snatched the pomegranate again because it was the last one, then she left.

Jawad is well-known for his evil fame. His family is the controller of the village. Indeed, they are so powerful and notorious. Unfortunately, Amal does not know him. For that reason, no one dared to help the poor little girl.

Jawad Sahib's utterance, "You won't mind if I take this for her, will you?" is Requestive as he wants Amal to give the pomegranate to him. Besides that, Jawad's utterance is easily noticed as Requestive because 'will' is a future likelihood that is common to make the indirect request. Although the utterance is interrogative form, Jawad is not expecting an answer but an action (giving him the pomegranate). The interrogative form of his directive shows indirectness. This is Jawad Sahib's first-time meeting with Amal. Sence he carefully considers his linguistic choice. In this case, Jawad's attributes do not contribute much to the sentence that he produces. He has authority and power over Amal, but Jawad prefers to use Requestive to sound more polite because there is a distance between them. It is a matter of distance between participants. 


\subsection{Requirements}

The speaker requires the hearer to do his intention. Doing that action is required as the speaker has sufficient or strong reason over the action. There is no other option; the hearer must do what the speaker says. The degree of force is stronger in Requirement than Requestives because in Requirement the hearer really must do it. The data show that the total of Requirement is seventy two (72) utterances.

Datum 3

Amal

: "The baby is coming. Aren't you excited to meet your new brother or sister?"

Safa \& Rabia : [no response]

Amal

: "Let's go in your bedroom and dress up your dolls while we wait. We can show them to the baby soon." (p. 17)

Amal's mother is unexpectedly giving birth to her fifth child outside of the prediction. Hearing this news, Amal is running as fast as she can to reach home. She is very worried about her mother and wants to accompany her. Sadly, she cannot stay in the birth room since an unmarried girl should not be there. Parvin, a neighbour of Amal's family who helps Mehnaz giving birth, asks Amal to help to watch the little sisters Safa and Rabia. They are just little kids and have not gone to school yet.

Amal's utterance, "Let's go in your bedroom and dress up your dolls while we wait", is a Requirement. It is classified as a Requirement because Amal requires her sisters to go to the bedroom and dress up the dolls. Indeed, Amal has authority over Safa and Rabia as the eldest daughter and sister in the family; and Parvin has granted her a duty to take care of them. She is physically, psychologically, and naturally powerful than them in this circumstance. Going to the bedroom and dressing up the dolls are the responsibility for Safa and Rabia to obey. The utterance embraces sufficient reason why Safa and Rabia have to do what Amal said. It is important for them not to bother their mother, who is still in the birth room, by doing such things.

Datum 4

Amal

: “A-Abu, I should have told you right away. But his car. It hit me. I was minding my own business walking home from the market. But he wouldn't let me be. He wanted to give me a ride home. He took my things and wouldn't give them back !"

Malik : "I don't care if he wanted your entire satchel of things! You give it to him. You drop everything at his feet, apologize, and walk away! Don't you have any idea the lengths that family goes to just to satisfy their goes? and Jawad Sahib especially!

Mehnaz : "Malik, enough. You're scaring the little ones." (p. 55)

The mishap that happened to Amal has spread out over the villagers. Amal was hit by Jawad's car, and she also shouted to him. Indeed, Amal's father has just known this rumour recently. He quickly investigates his daughter to make sure that the rumour is untrue. However, Amal's answer is the converse of what Malik hopes for. He becomes frightened and angry, hearing that the mishap is not just a rumour. As the most formidable person in the village, no one is willing to involve himself in everything attached to both Jawad and his family.

Malik's utterances "You give it to him" and "You drop everything at his feet, apologize, and walk away!" are Requirements. Malik requires Amal to do such things. Doing those 
actions is Amal's duty because if she does not do so, she will involve herself in serious trouble and probably it affects the entire family member. This is almost similar to the previous discussion; if Amal holds authority over her younger sisters, his father has the highest authority in the family. As Amal's father and head of the household, he has the legal power to decide how things are done. His power can cover things from material control to physical or psychological practice in nature.

\subsection{Questions}

Questions are almost similar to Requests. The main difference is in the output. The speaker requires an action to be performed in the Request, whereas in the Question the speaker demands certain information. The total of Questions from the data is one hundred and eighty four (184) utterances.

Datum 5

Amal

Miss Sadia : "That's not true ! Write about what you see ! Write about your dreams.

: "What would I write about? My little sisters ? My father's sugarcane fields and orange groves ? I love reading poems, but there's nothing for me to really write about. Our life is boring." Pakistan was founded by the dreams of poets. Aren't we of the same earth ?" (p. 3)

Amal likes to help Miss Sadia every day after school ends. Amal really admires Miss Sadia and loves to hear her story during college. She inspires Amal to be a great teacher someday. That day, Amal comes to Miss Sadia and wants to discuss the poetry project.

Amal's utterance "What would I write about" is obviously a Question. Amal is expecting an answer, not an action from Miss Sadia. She directly requests an idea for the poetry project. She needs a response or suggestion. Then, Miss Sadia's reply: "Write about what you see! Write about your dreams" is the requested idea that Amal asks.

Datum 6

Fatima

Amal

: "Have you ever tried the chocolate ones?"

Fatima

: "I haven't. Are they good?"

: "The best! She puts them out when her older sons visit because they love chocolate. They're a little expensive, so we can't eat too many or they'll notice. But I can get you one if you want." (p. 106)

Amal, Nabila, and Mumtaz are working together in the kitchen when Bilal, the other servant, comes. They are gossiping about Jawad Sahib while preparing the food. As a new servant, it is hard for Amal to catch up with them. Suddenly Fatima disrupts Amal's thought. She is preparing a snack for Nasreen's friends. Then, Amal helps Fatima preparing it for the guests.

Fatima is a 9-year-old servant at Khan Estate. She is younger than Amal, but she has been working long enough before Amal. She is very friendly to Amal. She is not very good at reading, and Amal becomes her fellow teacher later.

"Have you ever tried the chocolate ones?" is a question. The speaker wants to get certain information from the speaker whether he has ever tried chocolate. Fatima is expecting an answer about Amal's experience with chocolate. Amal's reply, "I haven't", explains in brief that she has no experience with eating chocolate. "I haven' $t$ " is the precise response to Fatima's directive because it is information solely, not truly an action. 


\subsection{Advisories}

The speaker convinces the hearer that doing this or that is recommended. The output is that the hearer will not just have belief about what is being said but actualize that belief. It can be inferred that Advisories occur for twenty five (25) times.

Datum 7

Nabila

Amal

: "How?"

Nabila

: "What if we told someone what we heard - told them we know they killed

that diplomat's son. Maybe then something would happen."

: "Right. They'll take our word over theirs." (p. 207)

Nabila has been acting strangely lately. One day she asks Amal to meet her and Bilal at the library after all people are asleep. Bilal and Nabila have already been at the library when Amal arrives. Nabila and Amal do not have a good relationship since the first time Amal came, but now they have been a good friend. Nabila begs Amal if she can help her to find Jawad's document on whoever has debt to him. A relative of Nabila was killed by Jawad, and his father and the dead body was found near the estate. However, the file which they found cannot change anything since Khan Family is incredibly powerful.

Amal's utterance "told them we know they killed that diplomat's son" is Advisory because Amal convinces and suggests to Nabila and Bilal that they probably can do something to change the situation. Amal wants Nabila and Bilal to be the courage to tell people that Jawad and his father had killed a diplomat's son. However, doing that action is preferable and not a force.

According to Bach and Harnish (1979: 289) [5], literal Advisory will mostly have imperative form. Thus, Amal's utterance above is direct Advisory. We can link the directness of Amal's utterance with her relationship with Nabila and Bilal. We can assume that the three have equal positions since the speaker does not need authority in producing Advisory. Here they are in the same position as servants at Khan Estate. Directness is chosen when the participants have a close relationship or at least they have known each other. Amal includes directness in her linguistic choice because Nabila and Bilal are her friends. There is no distant space in their communication practice.

Datum 8

Malik

Amal

Malik

: "Work is busier than usual, and your mother's still in bed."

: "We should phone Raheela Bibi. She'll know what to do."

: "It's not something the midwife can cure." (p. 33)

One day, Amal's father comes back home earlier. It is unusual for him to arrive home early. He seems worried much about his work and his wife. Amal's father has an orange grove and a sugarcane field inherited from his father. Work is busier than usual, and his wife has not been well improved after giving birth.

Amal's utterance, "We should phone Raheela Bibi", is Advisory. It is classified as Advisory because Amal tries to persuade her father that calling Raheela Bibi is much better than just let her mother take a rest without a complete examination. There is sufficient reason why doing that is a good idea. Her mother will probably be better soon. Amal wants her father to have a belief to perform calling the midwife. One thing that should be considered in this situation is not about authority but the distance between Amal and her father. In general, 
social norms, a daughter seems impossible to use directness to parents. That reality is reflected in the situation in datum 8 . Amal used indirectness to respect his father, and of course, it sounded more polite. Her indirectness indicates a social norm practice between daughter and father.

\subsection{Prohibitives}

Prohibitive is actually Requirement but with exception. If in Requirement the speaker requires the hearer to do something, in Prohibitive the speaker does not allow the hearer to do something. The data reveal that Prohibitives appear for sixteen (16) times.

Datum 9

Amal

: "But, Seema, I can't write a poem without a lesson on it. And how can I take the tests?"

Seema

: "I'll test you. I talked to Miss Sadia, and she agreed : as long as you keep up with your work and take the tests, she'll keep you on the roster. I also promised her I'd take good notes and teach you the lessons myself. Even the poetry lesson. Don't look at me like that ! I can do it ! And I'll teach you everything I learn. Because you are coming back." (p. 97)

Amal Amal is still staying at the house because her father does not allow her to attend school. She is facing a dilemma between attending school and helping her mother. The exam tests are going on, but Amal is unsure that she can go to school while her mother's health has not improved yet. Besides, she also has already given up that her father will let her have a chance to attend school again.

Although Amal has already lost hope, Seema wants to help her. On the afternoon after school, Seema hands school's assignments and tests to Amal. She reassures Amal that she can be a fellow teacher so that Amal can follow the school's timeline.

"Don't look at me like that!" is categorized as Prohibitive. Seema prohibits Amal not to despise her about the fellow teacher idea. This Prohibitive has the possibility to exist although Seema is younger than Amal, and she does not have authority over Amal. It can occur because it depends on the ongoing topic and situation of speaking. Moreover, in real social practice, siblings are common to use Prohibitive toward each other but not in all situations. Seema requires Amal to believe her about the fellow teacher job. After some days of absence from school, Seema is more 'educated' than Amal. As a result, that Prohibitive has sufficient reason why Amal needs to trust Seema. She can teach Amal the lessons which Amal does not get.

Datum 10

Mehnaz

: “Amal I know he's your friend, but you're not a little girl anymore. $\underline{\text { You }}$ can't spend so much time with him."

Amal : "But he's like our brother. How can I not see him ?" (p. 11)

Amal and Omar have been best friends since they were babies. They spend most of their time together in their secret place. Omar's mother works for Amal's father in his sugarcane and orange grove. That makes Omar and his mother a part of Amal's family. Even so, Amal's mother is worried about their friendship. She has reminded Amal not to get too close to the opposite sex.

Mehnaz's utterance, "You can't spend so much time with him”, is Prohibitive. She forbids Amal to stay close to Omar. Mehnaz's prohibition is reasonable; their neighbour will start 
gossiping about Amal and Omar if Amal cannot keep a distance from him. Because Mehnaz is Amal's mother, she holds legal authority over her daughter. Getting too close to Omar is not allowed for Amal. She must obey Mehnaz's prohibition. There is no other choice than that prohibition. Prohibition of doing something is commonly given from mother to daughter. Mehnaz's power is almost identical to Malik, just as discussed in datum 4. She dominates Amal in terms of economic and metaphysical power.

\subsection{Permissives}

The speaker gives permission the hearer to do certain action freely. The speaker's utterance is entitled to the hearer. Therefore, the hearer can do something with no doubt. There are only five (5) Prohibitives.

Datum 11

Nasreen Baji : : "Would Jawad Sahib let me?"

Amal : "Why wouldn't he ? You have time off. It's entitled to you." (p. 153)

Amal is Nasreen Baji's personal servant. She, together with Amal, goes to Lahore by a car driven by Ghulam after Jawad refuses to accompany Nasreen. They pass Amal's village on the way to Lahore city. Amal and Nasreen are talking about the villagers. They are familiar with the village and its people because both of them come from the same place. Nasreen Baji asks Amal about the loan borrowed by Shaukat for dowry, but Amal tells her that she does not know anything about that news because she cannot contact her family. Jawad Sahib took Amal's phone. As a result, Amal has not talked to her family since she arrived at Khan Estate. Nasreen feels sorry about her son's attitude. Actually, all servants can bring their phones. Thence, she lets Amal enjoy several days off to meet her family, friends, and neighbours.

Nasreen's utterance "You have to time off" is Permissive. She allows Amal to have days off from work. Nasreen permits Amal to feel free to do something. She has the authority to grant Amal that Permissive as Amal's master. Therefore, Amal can take a holiday without a doubt. It is clear that Nasreen holds the highest control over the situation. Nasreen has wider power compare to the other characters in the novel. First, she is the eldest. Second, she has many attributes which she gains as Sahib's family, like richness, fame, and privilege. Third, she is Amal's master. Their power distinction looks so obvious.

Datum 12

Amal

Mehnaz

$$
\begin{aligned}
& \text { : “I'm sorry. } \\
& \text { : "Don't be. You are free here." (p. 159) }
\end{aligned}
$$

Amal has finally visited home after Nasreen Baji gave her a few days off. This is the day that Amal has been waiting for a long time. She is very happy to see her family again. She cries, and everything sounds quiet for seconds. Amal apologizes to her mother that she must leave home.

Mehnaz's utterance above is Permissive because she permits the hearer not to perform an action but feel free to do something instead. The utterance "You are free here" is not a statement about information only. Amal's mother, in virtue of her authority, grants Amal freedom. Amal does not have to do the chores or help to watch her little sisters. It implies that Amal can do anything freely while she is at home now. 


\section{Conclusion}

Each character in "Amal Unbound" possesses different qualities of background such as age, social status, role, and education. It can be seen that the utterance relies on non-linguistic phenomena. Mostly, the powerful characters will have the tendency to use more Permissive, Prohibitive, or Requirement. They dominate the other, whose power is less. However, social norm or context is also at the forefront of the speaker's consideration because it usually pertains to politeness. Thus, although a character is superior to his interlocutor, the consideration of that social norm in linguistic choice is more important. We have seen how Jawad in datum 2 refers to use Requestive, even though he has power as the controller of the village. The reason is simply that he has never met Amal before. He considers the social norm beyond his superiority. On the other hand, the discussion in datum 4 also shows how Requirement is spoken from Seema, who seems powerless to Amal. The topic of speaking is the major reason why that Requirement occurs. In the end, the linguistic choice is determined by character qualities and other non-linguistic factors.

\section{References}

1. S. C. Levinson, Pragmatics, (Cambridge University Press Cambridge, 1983)

2. J. L. Mey, Pragmatics: An Introduction (2 ${ }^{\text {nd }}$ ed.), (Blackwell Publishing Oxford, 2001)

3. S. Rushforth, Ant. Ling. 27, 387-411 (1985)

4. J. R. Searle, Expression and Meaning, (Cambridge University Press Cambridge, 1979)

5. K. Bach, R. M. Harnish, Linguistic Communication and Speech Acts. In Language, (MIT Press, 1979)

6. R. Wardhaugh, J. M. Fuller, An Introduction to Sociolinguistics ( $7^{\text {th }}$ ed.), (John Wiley \& Sons, Inc, Chichester, 2015)

7. N. Fairclough, Language and Power (2nd ed.), (Routledge, 2013)

8. Kiklewicz, LP, 53, 69 (2011).

9. P. J. Hofmann, Language Politeness: Directive Speech Acts in Brazilian Portuguese, Costa Rican Spanish and Canadian English, (State University of New York, 2003)

10. J. Holmes, An Introduction to Sociolinguistics (4 ${ }^{\text {th }}$ ed.), (Routledge New York, 2013)

11. G. Yule, Pragmatics, (Oxford University Press Oxford, 1996)

12. G. A. Mahendra, JH, 22, 253-260 (2018)

13. B.T. Pamungkas, Rustono, Y. Utanto, JPE, 7, 211-219 (2018)

14. D. Winarti, I.D.P. Wijana, S. Poedjosoedarmo, Hum., 27, 305-316 (2015) 